\title{
Depresjon før og etter fødselen
}

\author{
Flere begreper er i bruk for depresjon som rammer kvinner i forbin- \\ delse med svangerskap og fødsel: svangerskapsdepresjon, fødsels- \\ depresjon, barseldepresjon og postpartumdepresjon. Er alle uttrykk \\ for det samme?
}

Det er godt dokumentert at tiden etter en fødsel er en risikoperiode for kvinners psykiske helse (1). Resultatene fra en stor dansk registerstudie tyder på en mer enn dobbelt så stor risiko for å trenge psykisk helsehjelp de første tre månedene etter en fødsel enn et år senere og en omtrent tredoblet risiko for å rammes av depresjon i løpet av de første fem månedene etter fødselen (2).

\section{Ulike begreper}

Depresjon som rammer kvinner i forbindelse med svangerskap og fødsel kalles gjerne i engelskspråklig litteratur for «postnatal depression» eller «postpartum depression». Ordene kommer fra latin: «post» = «etter», «natal» $($ fra «natalis») $=$ «tidspunkt for fødsel» og «partum» (fra «partus») $=$ «fødsel». Begge disse begrepene sikter til en depresjon som inntreffer i tiden etter en fødsel, dvs. en «etterfødselsdepresjon». Begrepet «barseldepresjon» er derfor den mest presise oversettelsen av begrepet «postpartum-» og/eller «postnatal» depresjon.

«Svangerskapsdepresjon» sikter til en depresjon som oppstår under svangerskapet. Imidlertid brukes dette begrepet i praksis ofte som en direkte oversettelse av begrepet «postpartum depression». Også begrepet «fødselsdepresjon» blir brukt noe upresist. Begrepet antyder dessuten en årsakssammenheng. Det finnes ikke belegg for at selve

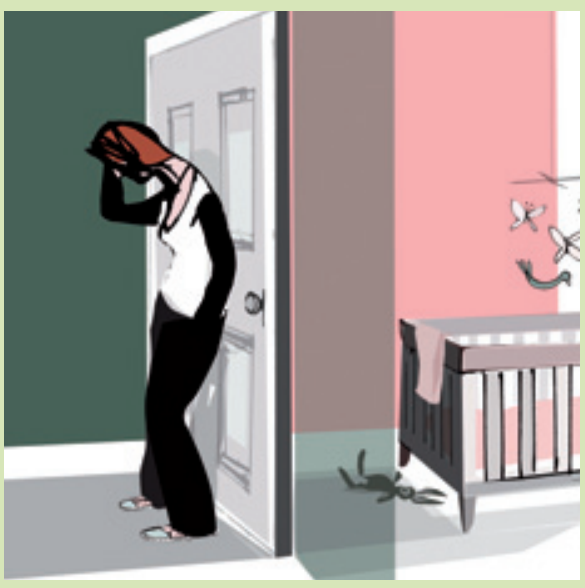

Illustrasjon (C) Science Photo Library/GV-Press/ NordicPhotos fødselen er en direkte årsak til utvikling av postpartumdepresjon, men som andre store livshendelser kan også begivenhetene i forbindelse med fødsel og spedbarnsomsorg utløse latente psykiske plager og lidelser (3). De fleste undersøkelser tyder på at når depressive plager oppstår i denne fasen av livet, er det ofte vansker som kvinnen har hatt tendenser til tidligere i livet.

Det finnes foreløpig ikke belegg for at postpartumdepresjon er en egen type depresjon med helt andre årsaksfaktorer enn depresjon som oppstår i andre perioder av livet (4). Flere forskningsfunn tyder imidlertid på at barselperioden kan være en følelsesladet tidsepoke som hos noen utløser gamle bekymringer (3). Søvnmangel, problemer med amming, følelse av stort ansvar, tretthet og fysiske plager kan alle være med på å utløse dette. Til tross for relativt omfattende forskning er det foreløpig ingen støtte for ideen om at hormonelle faktorer i vesentlig grad bidrar til å utløse en barseldepresjon (5). Et unntak er de ca. $1 \%$ av nybakte mødre som har en thyreoideadysfunksjon. Hos disse kvinnene starter depresjonen 2-5 måneder etter fødselen (6).

\section{Barseltårer}

Det er viktig å ikke forveksle postpartumdepresjon med barseltårer. I dagene etter en fødsel blir mange mødre lett beveget og gråter lett, såkalt «maternity blues» eller barseltårer. Barseltårer er en forbigående følelsesmessig labilitet som oppstår i løpet av den første uken etter en fødsel. Tilstanden rammer $50-80 \%$ av alle nybakte mødre og varer omtrent 2-3 døgn. Man regner med at det primært er hormonelle faktorer som er hovedårsaken til barseltårer og at psykologiske faktorer ikke bidrar i noen særlig grad (7). En blues (barseltårer) kan imidlertid også ses på som en utmattelsesreaksjon etter en periode preget av spenning og uro for fødselen og for om barnet er normalt. Søvnmangel før og i forbindelse med fødselen kan bidra. Barseltårer er så vanlig at det regnes som en normaltilstand. Dersom tilstanden ikke går over eller er svært kraftig, kan det være et tegn på en begynnende depresjon $(8,9)$.

\section{Konklusjon}

I praksis brukes de fire begrepene svangerskapsdepresjon, fødselsdepresjon, barseldepresjon og postpartumdepresjon om hverandre. Imidlertid kan de to førstnevnte oppfattes som noe mindre presise enn de to sistnevnte. Jeg vil derfor anbefale å bruke barseldepresjon eller postpartumdepresjon i faglige sammenhenger.

I senere år har man i økende grad begynt å bruke begrepet «perinatal depression», hvor man inkluderer både perioden før fødselen (antenatal) og tiden etter fødselen (postnatal). Grunnen er at man i flere studier har funnet omtrent like høyt nivå av depresjonssymptomer i slutten på svangerskapet som etter fødselen $(10,11)$. Kanskje vil perinataldepresjon etter hvert bli det foretrukne begrepet?

\section{Malin Eberhard-Gran}

malin.eberhard-gran@fhi.no

Nasjonalt folkehelseinstitutt

Postboks 4404 Nydalen

0403 Oslo

og

Akershus universitetssykehus

Oppgitte interessekonflikter: Ingen

\section{Litteratur}

1. Eberhard-Gran M, Slinning K. Nedstemthet og depresjon i forbindelse med fødsel. Oslo: Folkehelseinstituttet, 2007

2. Munk-Olsen T, Laursen TM, Pedersen CB et al. New parents and mental disorders - A populationbased register study. JAMA 2006; 296: 2582-9.

3. Musters C, McDonald E, Jones I. Management of postnatal depression. BMJ 2008; 337: 399-403.

. Brockington I. Postpartum psychiatric disorders. Lancet 2004; 363: 303-10.

5. Hendrick V. Psychiatric disorders in pregnancy and the postpartum period: principles and treatment. Totowa, NJ: Humana Press, 2006.

6. Harris B. Biological and hormonal aspects of postpartum depressed mood - working towards strategies for prophylaxis and treatment. Br J Psychiatry 1994; 164: 288-92.

7. Boyce P. Personality dysfunction, marital problems and postnatal depression. I: Cox J, Holden J. red. Perinatal psychiatry. London: Gaskell, 1994.

8. Cox JL, Connor Y. Kendell RE. Prospective study of the psychiatric disorders of childbirth. Br J Psychiatry 1982; 140: 111-7.

9. Henshaw CA. A longitudinal study of postnatal dysphoria. MD thesis. Aberdeen: University of Aberdeen, 2000

10. Evans J, Heron J, Francomb H. Cohort study of depressed mood during pregnancy and after childbirth. BMJ 2001: 323: 257-60.

11. Eberhard-Gran M, Tambs K, Opjordsmoen S et al. Depression during pregnancy and after delivery a repeated measurement study. J Psychosom Obstet Gynaecol 2004; 25: 15-21.

Manuskriptet ble mottatt 16.4. 2009 og godkjent 20.4. 2009. Medisinsk redaktør Raida Ødegaard. 